Review essay

\section{Cities, hinterlands, and critical theory}

Critique of Urbanisation: Selected Essays, Neil Brenner (Ed.). Birkhäuser Verlag, Basel (2016). p. 294 pp £26.99, ISBN: 978-30356-0797-0

Cities of Power: The Urban, the National, the Popular, the Global, Göran Therborn. Verso, New York (2017). 408 pp £20.00. ISBN-13: 978-1-78478-544-4

Against the backdrop of planetary urbanisation, the relation of cities to their respective hinterlands of various sorts is returning to the centre of analysis in human geography, political economy, sociology, and world history. The two volumes treated here are recent examples of this resurgence of interest, but are quite far from one another in their respective objectives, structures, styles, and ultimately in their usefulness for critical political engagement with key questions emergent in 21st century urban geography.

As a compendium of previously published articles (2000-2016), either solely or jointly authored by Neil Brenner, Critique of Urbanisation introduces the Critical Urban Theory that has coalesced around Brenner, Jamie Peck, Nik Theodore, David Wachsmuth, inter alia, and that alloys human geography, urban design, and critical theory. Subtly distinguished from 'critical urban studies' (Marcuse \& Imbroscio, 2014), the agenda here is primarily to provoke new trajectories for urban studies by questioning the established epistemological and phenomenological predicates of urban geography and sociology, and to conceive of novel conceptualizations, methods, and horizons for thinking and acting upon 'the urban'. The collection is nothing less than a call to arms, a kind of manifesto for critical theoretical re-engagement with the fundamentals (but not foundations) of urban thinking in the 21st century.

A major implication of this re-engagement requires a closer cross fertilisation with developments in critical political and social theory. Enter Therborn's Cities of Power, which joins the picture from the other direction. Whilst Brenner's volume makes a clear statement adumbrating a prospective academic and practical agenda by problematizing the bases of urban theory as it stands, Therborn's book is a self-confessed oblique foray into urban studies research, representing as it does a sociological theorist's attempt to place cities into political matrices of power in the world history of Modernity. The result is that the former offers a cumulative expression of an emerging field of intellectual endeavour (Critical Urban Theory), which the various contributors have willed into its place on the academic landscape, whilst the latter offers a ranging and sometimes unfocused exploration of themes relating in various ways to historical urbanity.

Cities of Power is principally concerned with the political relationship of cities to the nation-states in which they have been situated throughout Modernity, which is of course something that has increasingly become problematized (see Sassen, 2000). The first two-thirds of the book, closer to Croce's 'anthology of information' than a history proper, is given over to a history of politically significant cities the world over, principally capital cities, and seeks to situate them into modernisation pathways and the emergence of the nation-state in particular as a dominant and enduring paradigm of modern political organisation. The book's historical meanderings through the planning, design and memorialisation in cities across the Globe impart little more than an iteration of an insight that Therborn sums up on page 303: 'architecture is sociology turned into built form', and that this sociology can indicate power in the relations between urbanisation processes and broader historical, political, and geographical matrices of social structures and frameworks in which they are situated.

It is eventually in the third portion of the work - the 'global moment' in the urban history of the world - that we come to the contemporaneously relevant treatment of the current impasse: the apparent disintegration of the nation-state, the rise of global cities, and the implications for a reconfiguration of 'cities of power' to the hinterlands of human habitation. Bracketing 'political economy and world capitalism' in his treatment of our current 'global moment', Therborn's argument leads us to a 'political urbanism' (Therborn, 2017: 288), in which 'style' and 'power' are offered as the two decisive components of 'the current global moment of urban history'. This conclusion is unsurprising, given his prior emphasis on iconographies of power in the historical odyssey that is the first two-thirds of the book. This 'political urbanism', which constitutes a partial turn away from the materiality of political economy in favour of consideration of the symbolic, is therefore a concentration on the semiotics, design, and symbolic reproduction of power in the urban space.

Despite its insights into semiotic operations of power, I would argue that Cities of Power offers the wrong kind of contribution that political and social theorists can make to the emerging field of Critical Urban Theory, and this opinion can be expressed succinctly by reference respectively to a 'sociology of categories' in distinction to a 'sociology of relations'. Therborn's instinctual taxonomic and classificatory tendencies are indicative of a 'sociology of categories' familiar from post-war social science and its positivist, scientist, and nomothetic commitments, and with its scientific compulsions to classify and to render the continuum of extended phenomena into discrete typological unities. This kind of 'taxonomic folly' (Jessop, Brenner, \& Jones, 2008, pp. 395-396) is evinced in Therborn's running historical classification of cities into four classificatory groups that structures his book - 'European cities', 'settler colony cities', 'post-colonial nationalist cities', and 'cities of reactive modernisation'.

Cities of Power therefore stands in clear distinction to the stated objectives of Critical Urban Theory presented in Critique of Urbanisation: the reassessment of reigning concepts, epistemologies, and 
definitional parameters in the human geography of urbanity. More precisely, Critical Urban Theory seeks to combat the 'epistemology of "naïve objectivism"' regnant in the social sciences, whereby political geographical formations are 'conceived as self-evident empirical entities that can be transparently understood and instrumentally manipulated by a neutral observer occupying a vantage point external to the sites and processes being investigated' (Brenneret al., 2016, p. 20). Instead, what is required for critical theoretical investigation is a recognition of the 'practical situatedness of all forms of knowledge', as well as a 'rigorous epistemological reflexivity' when it comes to the 'changing contexts, conditions and mediations of that situatedness in relation to ongoing processes of historical-geographical restructuring'. Martín Arboleda's Preface makes clear that 'one of the most analytically crucial and politically urgent challenges for contemporary urban interventions is to expand their field of vision beyond inherited, naturalised jurisdictional and sociological visions' (Brenneret al., 2016, p. 11), which of course includes unitary concepts like the State, Nation, Class, City, etc. This is a movement that is clearly inverse to Therborn's 'sociology of categories', a sociology that takes us back into the social science of the 20th century, rather than forward into the prospective struggles and counter-conducts of 21st century urban existence.

The 'sociology of categories' is a gravitation toward one feature in particular that is characteristic of discourses on the city/hinterland from which Critical Urban Theory is struggling to depart, namely, away from 'ahistorical dualisms' and binaries like interior/exterior, city/countryside, urban/rural, society/nature, or material/symbolic (Brenneret al., 2016, pp. 218, 265), but these are precisely the kinds of binaries that Therborn's 'sociology of categories' restores. In this latter work, the canonical conceptualisations of urban theory, far from being challenged or problematized, are rather reaffirmed. Reorientation onto a 'sociology of relations', on the other hand, is essential to understanding 'hinterlands', the asymmetries and uneven developments that the notion entails (Brenneret al., 2016, p. 162), and onto the contradictions within dialectical relationships that ought to be viewed historically rather than statically. Epistemological introspection with conceptual re-invention is necessary for handling intellectually, but also practically, the immense complexities thrown up by the disintegration of discrete and coherent delimitation of all those 'dualisms' inherent to conventional thinking on 'the urban' - starting with the 'city-hinterland' dichotomy itself.

It seems that Critical Urban Theory aims to destabilize formations that 'sanctify, naturalize or legitimate extant sociospatial arrangements and the manifold injustices, dispossessions, dislocations, degradations and irrationalities upon which they are grounded' (Brenneret al., 2016, p. 19), and in so doing seeks to restore social relations to the centre of analysis. This is an essential move, not only to inject political economy back into urban studies critique (Brenner, Madden, \& Wachsmuth, 2011), but also if we wish to grasp the reconfigurations of power that cities and urban spaces emplace in our contemporary social experiences. Additionally, an epistemological orientation around relations is more congenial to the "constant reinvention of the framing categories, methods and assumptions of critical urban theory in relation to the rapidly, unevenly mutating geographies of capitalist urbanisation, especially in the contemporary era of hyperfinancialized, planetaryscale spatial, institutional and ecological transformation' (Brenneret al., 2016, p. 22). Critical Urban Theory's preference for foregrounding 'relations' in the theoretical interrogation of 'space' is part of a general move in critical geography toward integration of the various waves of critical theory that have borne upon human geography for some decades now (Marxian, Post-Structuralist, Post-Freudian, etc.), coalescing principally around spatial lexica of 'territory', 'place', 'scale', and 'networks' (TPSN), each of which constituting the core concept of a given chapter of the 'spatial turn'. Critical Urban Theory seeks to end the isolated treatment of these jockeying elements, and to integrate them rather into "concrete-complex analyses that are systematically, reflexively attuned to the polymorphy of sociospatial relations' (Jessop et al., 2008, p. 392). Whilst they each 'spiral in' from one or more of the four entry points, this is an approach to spatiality that one can also find to varying degrees in the political economy of John Agnew (Territory), Stuart Elden (Territory), Erik Swyngedouw (Scale), Anssi Paasi (Territory), Doreen Massey (Place), Sallie Marston (Scale), Martin Jones, Gordon Macleod, inter alia, all of whom build to varying degrees on the longstanding works of Henri Lefebvre, David Harvey, Edward Soja, and which attempt to reinvent a political economic critique of the urban idiom that is strengthened, rather than weakened, by the nuances, doubts, and hesitations introduced by poststructuralist deconstruction over recent decades.

The relational view is more propitious for integration of the necessary aesthetic, cartographic, processual developments in critical social theory, to which the epistemological agenda of Critical Urban Theory aims. In particular, it is much more promising for the bringing of political economic critique into contact with the strident progress being made in urban assemblage-thinking, a contact that is sorely needed to enhance the critical potential of both materialist traditions. As the urban assemblage is increasingly becoming a strategically decisive political formation in the reconfiguration of human organisation, specifically as a conjunction of the partial disintegration of the nation-state ensemble and the emergence of a manifestly global theatre of human activity. Add to this a reformation in ontological and epistemological predicates, and the implication is that the canonical relation of city-hinterland in the history of political geography has reached a moment of crisis both materially and immaterially. These two works of Brenner (et al.) and Therborn represent two strategic reactions to that crisis, and to my mind Critique of Urbanisation indicates the more illuminating, stimulating, and politically promising way forward.

In our current period of capitalist restructuring that is the neoliberal regime of capital accumulation, 'the urban' constitutes one of the strategically pivotal idioms through which this restructuring is taking place, and by which wider populations are controlled, subordinated, and dominated. This means that critique of 'urban ideologies' is especially needed at present, in order to mobilise counter-conducts and resistance strategies to the power immanent to global cities. Critical Urban Theory not only offers this kind of critique but also opens up greater possibilities for strategic exploration of the 'disjunction between the actual and the possible' in contemporary urban life (Brenner et al., 2011, p. 29), and in so doing, it forces a space for agential political intervention between the contingent and the necessary in social experience.

\section{Conflict of interest statement}

There is no confect of interest to report regarding the submission 'Cities, Hinterlands, and Critical Theory'.

\section{References}

Brenner, N., Madden, J., \& Wachsmuth, D. (2011). Assemblage urbanism and the challenges of critical urban theory. City, 15(2), 225-240.

Jessop, B., Brenner, N., \& Jones, M. (2008). Theorizing sociospatial relations. Environment \& Planning $D, 26(3), 389-401$.

Marcuse, P., \& Imbroscio, D. (2014). Critical urban theory vs. Critical urban studies. International Journal of Urban and Regional Studies, 38(5), 1904-1917.

Sassen, S. (2000). The global City: Strategic site/new frontier. American Studies, 41(2/ 3), 79-95. 
John Welsh

Department of Political and Economic Studies, University of Helsinki, Unioninkatu 37, Helsinki 00014, Finland E-mail address: john.welsh@helsinki.fi.
@Welshentag

14 March 2018

Available online 26 March 2018 